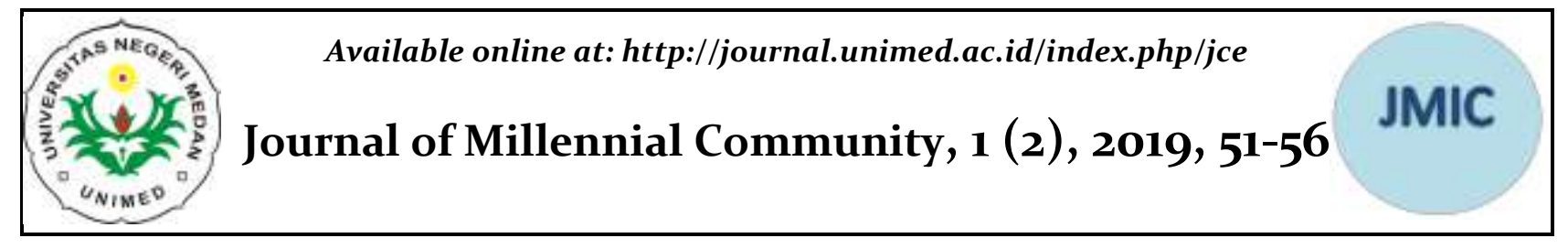

\title{
HUBUNGAN TINGKAT PENDIDIKAN PASANGAN USIA SUBUR (15-49 TAHUN ) DENGAN KEBERHASILAN PROGRAM KELUARGA BERENCANA
}

\author{
Meina Imelda Siregar ${ }^{1}$, Nasriah $^{2}$ \\ ${ }^{1}$ BKKBN Sumatera Utara ${ }^{2}$ Universitas Negeri Medan \\ imel.imelda@gmail.com
}

\begin{abstract}
Abstrak
Masalah pertumbuhan penduduk yang besar sangat dikhawatirkan terjadinya ledakan penduduk dan jumlah penduduk yang besar ini bila tidak dijadikan manusia yang produktif maka menjadi tanggungan negara. Oleh karena itu, pemerintah membuat suatu program yang mampu menekan jumlah pertumbuhan penduduk tersebut dengan adanya Program KB. Jenis penelitian yang digunakan adalah deskriptif kuantitatif dengan populasi sebanyak 400 pasangan. Jumlah populasi yaitu 100 responden. Instrument yang digunakan dengan menggunakan angket tertutup, alat pengumpul data yang digunakan yaitu observasi dan angket. Berdasarkan 100 responden, 27 responden menamatkan pendidikan SMP, 12 responden menyatakan pelaksanaan program KB baik, 7 responden menyatakan cukup baik, 8 responden menyatakan tidak baik. Berdasarkan 51 responden tamatan SMA, 11 responden pelaksanaan program KB baik, 33 responden menyatakan cukup baik, 7 responden menyatakan tidak baik. Berdasarkan 22 responden tamatan PT, 6 menyatakan pelaksanaan program KB baik, 11 responden menyatakan cukup baik dan 5 responden menyatakan tidak baik. Berdasarkan hasil perhitungan Chi Kuadrat, didapatkan hasil $31 \%$ korelasi antara tingkat pendidikan pasangan usia subur terhadap tingkat keberhasilan keluarga berencana.
\end{abstract}

Kata Kunci: Keluarga berencana, Pendidikan, Usia subur

\section{Relationships Of Education In Fertile Age Couples (15-49 Years) With The Success Of The Program Family Planning}

\begin{abstract}
The problem of large population growth is very much feared by a population explosion and this large population if not made into a productive human being is the responsibility of the state. Therefore, the government makes a program that is able to reduce the population growth with the KB program. This type of research is quantitative descriptive with a population of 400 couples. Total population is 100 respondents. The instrument used was using a closed questionnaire, data collection tools used were observation and questionnaires. Based on 51 high school graduates, 11 respondents said that the family planning program was good, 33 respondents said that it was good enough, 7 respondents said that it was not good. Based on 22 PT graduates, 6 stated that the family planning program was good, 11 respondents stated that it was quite good and 5 respondents said that it was not good.
\end{abstract}


Based on the calculation of Chi Square, the results obtained $31 \%$ correlation between the level of education of fertile age couples with the success rate of family planning.

Keywords: Family Planning, Education, Fertile Age

\section{PENDAHULUAN}

Pembangunan nasional bertujuan mewujudkan masyarakat adil dan makmur baik materil maupun berdasarkan Pancasila dan UndangUndang Dasar 1945, sebagaimana tercantum dalam Pembukaan Undang_undang Dasar 1945 alinea IV yang merupakam tujuan nasional bangsa Indonesia yang salah satunya adalah untuk memajukan kesejahteraan umum, yaitu dengan mewujudkan masyarakat yang sejahtera lahir dan batin. Dalam mewujudkan perbaikan tingkat kehidupan dan tingkat kesejahteraan diperlukan partisipasi seluruh warga Negara Indonesia.

Data Badan Pusat Statistik (BPS) Tahun 2010 menunjukkan pertumbuhan penduduk selama tiga dasa warsa terakhir meningkat dengan pesat, hal tersebut dapat dilihat dari tingkat pertumbuhan penduduk dari tahun 1990 yang berjumlah 179.378.946, pada tahun 2000 yang berjumlah 206.246.595, dan pada tahun 2010 yang berjumlah 237.641.326. Disatu pihak jumlah penduduk yang besar mempunyai peranan yang sangat penting bagi suksesnya Pembangunan Nasional yaitu sebagai sumber daya manusia yang potensial dan produktif. Tetapi di lain pihak, jumlah penduduk yang besar dapat mengganggu upaya pemerintah dalam hal pencapaian pemerataan kesejahteraan secara umum sehingga permasalahan dalam hal kependudukan memerlukan pemecahan masalah yang lebih lanjut.

Dalam rangka menunjang usaha tersebut telah diusahakan untuk memasukkan pendidikan kependudukan ke dalam pendidikan formal maupun pendidikan non formal. Dengan adanya pendidikan kependudukan, maka pemerintah berusaha mengatasi masalah penduduk dengan menumbuhkan kesadaran di lingkungan keluarga terutama suami isteri melalui program Keluarga Berencana (KB). Dengan dilaksanakannya program Keluarga Berencana, diharapkan mampu mengatasi masalah kependudukan seperti menekan tingkat kelahiran sehingga tidak melebihi kemampuan produksi pangan, sebab melalui program Keluarga Berencana diharapkan tercipta Norma Keluarga Kecil Bahagia dan sejahtera (NKKBS).

Untuk kelurahan Sari Rejo sendiri, ada sekitar 3.056 pasangan usia subur, dan 2.113 adalah peserta KB aktif 943 adalah pasangan usia subur yang tidak mengenakan alat kontrasepsi apapun. Jumlah yang cukup besar bila dibandingkan dengan kelurahan lain, karena hampir separuh dari jumlah PUS dari lima kelurahan berada di kelurahan Sari Rejo ini (Data Akseptor KB kelurahan Sari Rejo/September 2012).

Maka dari itu, untuk membuat program Keluarga Berencana berhasil diperlukan kepedulian dari setiap aspek 
masyarakat terutama kaderkader/pelayanan Keluarga Berencana untuk mensosialisasikan program Keluarga Berencana. Dan juga dibutuhkan partisipasi pasangan usia subur untuk mencapai keberhasilan program Keluarga Berencana yaitu dengan menggunakan kontrasepsi.

Berdasarkan pembahasan di atas, masih banyak pasangan usia subur yang berada pada tingkat kesejahteraan yang rendah yaitu 617 masih berada di tingkat pra sejahtera dan sejahtera tingkat pertama, yaitu kurangnya kebutuhan akan sandang, pangan, papan, kesehatan, pendidikan, agama, keluarga berencana, interaksi dalam keluarga, interaksi dalam lingkungan, informasi, dan transportasi. (Data Akseptor KB keluarahan Sari Rejo/September 2012).

\section{Rendahnya}

tingkat

kesejahteraan itu dapat terlihat dari kurang sadarnya pasangan usia subur untuk mengikuti program Keluarga Berencana di lingkungan VI kelurahan Sari Rejo kecamatan Medan Polonia tahun 2012. Maka dari itu peneliti tertarik untuk mengetahui Hubungan Tingkat Pendidikan Pasangan Usia Subur (15-49 tahun) dengan Keberhasilan Program Keluarga Berencana di lingkungan VI kelurahan Sari Rejo kecamatan Medan Polonia karena peneliti ingin mengetahui apakah program keluarga berencana di kelurahan tersebut berhasil atau tidak. Menurut pengamatan yang dilakukan peneliti, sebagian masyarakat di daerah tersebut masih berpendidikan rendah yaitu hanya menamatkan pendidikan dasar dan pendidikan menengah lanjutan tingkat pertama, sehingga mendorong peneliti ingin mengetahui pengaruh tingkat pendidikan pada pasangan usia subur Page | 53 dalam mengikuti program Keluarga Berencana

\section{METODE}

Penelitian ini dilakukan di Lingkungan 6 Kelurahan Sari Rejo Kecamatan Medan Polonia Propinsi Sumatera Utara. Dalam penelitian ini, populasi adalah semua pasangan usia subur yang isterinya berusia 15-49 tahun dan merupakan akseptor KB di lingkungan VI kelurahan Sari Rejo kecamatan Medan Polonia sebanyak 400 pasangan. Setelah populasi diketahui dengan jelas, maka peneliti menetapkan besar sampel sebesar 25 $\%$ dari jumlah keseluruhan jumlah sampel yaitu 100 akseptor KB yang diambil secara acak.

Peneliti menggunakan angket dan dokumentasi untuk memperoleh data penelitian yang diperlukan. Adapun tekhnik analisis data dalam penelitian ini adalah dengan menggunakan tekhnik/rumus Chi Kuadrat $\left(X^{2}\right)$ dan tekhnik Korelasi Kontingensi (KK). Adapun rangkaian rumus tersebut adalah sebagai berikut

$$
\begin{aligned}
\mathrm{X}^{2} & =\frac{(f o-f h)^{2}}{f h} \\
\mathrm{KK} & =\sqrt{\frac{x^{2}}{x^{2}+N}}
\end{aligned}
$$

Keterangan :

$\mathrm{X}^{2} \quad=$ Harga Chi Kuadrat

fo $\quad=$ Frekwensi Observasi 
fh $\quad=$ Frekwensi Harapan

$\mathrm{KK}=$ Harga Korelasi Kontingensi

$\mathrm{N}=$ Jumlah Responden Penelitian

\section{PEMBAHASAN}

Berdasarkan hasil penelitian dapat diketahui tingkat pendidikan responden penelitian. Sebanyak 100 orang yang ditetapkan sebagai sampel penelitian terdiri dari tingkat pendidikan tamatan SMP, SMA dan Perguruan Tinggi (PT). untuk mengetahui keadaan tingkat pendidikan responden dapat dikemukakan pada tabel berikut:

Tabel 1. Distribusi Frekuensi Data Tingkat Pendidikan

Berdasarkan pada tabel di atas dapat diketahui bahwa sebanyak 27 responden $(27,00 \%)$ adalah tamatan SMP, sebanyak 51 responden (51,00\%) adalah tamatan SMA dan sebanyak 22 responden $(22,00 \%)$ adalah tamatan PT. Dengan demikian dapat disimpulkan bahwa responden dalam penelitian ini dintinjau dari tamatan adalah lebih banyak dari tamatan SMA.

Tabel 2. Distribusi Frekensi Jawaban Responden Terhadap Pelaksanaan Program Keluarga Berencana

\begin{tabular}{cclcc}
\hline No & Tamatan & Pelaksanan & $\mathrm{F}$ & $\mathrm{F}_{\text {relatif }}$ \\
& & Program KB & & $(\%)$ \\
& & Baik & 11 & 21,57 \\
1 & SMA & Cukup & 33 & 64,71 \\
& & Baik & & \\
& & Tidak Baik & 7 & 13,73 \\
& Jumlah & & 51 & 100,00 \\
\hline
\end{tabular}

Berdasarkan pada tabel di atas dapat diketahui tanggapan responden dengan tingkat pendidikan SMA terhadap pelaksanaan program

keluarga berencana yaitu 11 responden $(21,57 \%)$ menyatakan pelaksanaan program berencana baik, 33 responden $(64,71 \%)$ menyatakan cukup baik, dan 7 responden (13,73\%) Page 54 menyatakan tidak baik.

Keluarga berencana adalah tindakan untuk membantu individu atau pasangan suami isteri untuk menghindari kelahiran yang tidak diinginkan, mendapatkan kelahiran yang diinginkan, mengatur interval diantara kehamilan, mengontrol waktu saat kelahiran dalam hubungan dengan umur suami isteri, menentukan jumlah anak dalam keluarga untuk meningkatkan kesejahteraan hidup masyarakat dengan menggunakan alat

\begin{tabular}{cccc}
\hline No & Tamatan & Jumlah & $\mathrm{f}_{\text {relatif }}(\%)$ \\
1 & SMP & 27 & 27,00 \\
2 & SMA & 51 & 51,00 \\
3 & PT & 22 & 22,00 \\
& Jumlah & 100 & 100,00 \\
\hline
\end{tabular}

kontrasepsi. Keluarga yang berhasil merubah cara hidupnya dengan keluarga berencana akan berdampak positif yaitu sudah ikut berpartisipasi dan ikut melaksanakan program pemerintah dalam usaha penanggulangan masalah pertumbuhan penduduk.

Dengan pendidikan yang baik, akan merubah pola pikir masyarakat dalam mengikuti dan mendukung program pemerintah dalam usaha penanggulangan masalah pertumbuhan penduduk tersebut dengan keikutsertaan masyarakat dalam mensukseskan Program Keluarga Berencana.

Berdasarkan hasil pengolahan dan analisa data penelitian diketahui bahwa responden penelitian sebanyak 100 orang yang terdiri dari tingkat/tamatan pendidikan yaitu SMP, SMA dan Perguruan Tinggi (PT). Dari sebanyak 
100 responden penelitian ini terdiri dari sebanyak 27 responden $(27,00 \%)$ adalah tamatan SMP, sebanyak 51 responden $(51,00 \%)$ adalah tamatan SMA dan sebanyak 22 responden $(22,00 \%)$ adalah tamatan PT. Dengan demikian dapat disimpulkan bahwa responden dalam penelitian ini dintinjau dari tamatan adalah lebih banyak dari tamatan SMA.

Selanjutnya tanggapan responden tingkat pendidikan SMP terhadap pelaksanaan program keluarga berencana yaitu 12 responden $(44,44 \%)$ menyatakan pelaksanaan program berencana baik, 7 responden $(25,93 \%)$ menyatakan cukup baik, dan 8 responden $(29,63 \%)$ menyatakan tidak baik.

Tanggapan responden dengan tingkat pendidikan SMA terhadap pelaksanaan program keluarga berencana yaitu 11 responden $(21,57 \%)$ menyatakan pelaksanaan program berencana baik, 33 responden $(64,71 \%)$ menyatakan cukup baik, dan 7 responden $(13,73 \%)$ menyatakan tidak baik. Tanggapan responden dengan tingkat pendidikan Perguruan Tinggi (PT) terhadap pelaksanaan program keluarga berencana yaitu 6 responden $(27,27 \%)$ menyatakan pelaksanaan program berencana baik, 11 responden $(50,00 \%)$ menyatakan cukup baik, dan 5 responden $(22,73 \%)$ menyatakan tidak baik.

Berdasarkan hasil hitung diperoleh harga Chi Kuadrat $\left(x^{2}\right)=10,760$ lebih besar dari harga kritiknya $=9,488$ ( $10,760>9,488$ ). Penerimaan hipotesa dilakukan bila harga Chi Kuadrat $\left(x^{2}\right)$ lebih besar dari harga kritiknya, maka hipotesa yang penulis kemukakan yaitu terdapat hubungan yang signifikan antara tingkat pendidikan pasangan usia subur (15 s/d 49 tahun) dengan keberhasilan pelaksanaan program keluarga berencana di lingkungan VI Kelurahan Sari Rejo Kecamatan Medan Polonia diterima dengan taraf kepercayaan $95 \%$ artinya kebenaran hipotesa dapat diyakini 95\%.

Hasil hitung sebesar 0,310 Page|55 menunjukkan bahwa korelasi antara variabel tingkat pendidikan usia subur (15 s/d 49 tahun) dengan keberhasilan pelaksanaan program keluarga berencana berada pada korelasi rendah. Untuk melihat seberapa besar tingkat hubungan antara kedua variabel berdasarkan persentasenya yaitu $0,310 \times 100 \%=31,00 \%$. Berdasarkan perhitungan indeks determinasi dapatlah dikatakan kontribusi tingkat pendidikan pasangan usia subur (15 s/d 49 tahun) adalah sebesar $31,00 \%$ dan sisanya $69,00 \%$ merupakan pengaruh diluar penelitian.

\section{KESIMPULAN}

Dukungan yang diberikan peserta usia subur dengan keterlibatannya dalam kegiatan program keluarga berencana yaitu sebanyak 29 responden memberikan keterlibatan secara baik, sebanyak 51 responden memberikan dukungan cukup baik dan sebanyak 20 responden (pasangan usia subur) kurang memberikan dukungan terhadap pelaksanaan program keluarga berencana. Dapat disimpulkan bahwa, dukungan pasangan usia subur terdapat pelaksanaan program keluarga berencana diterima cukup baik oleh masyarakat di lingkungan VI kelurahan Sari Rejo kecamatan Medan Polonia. Terdapat hubungan yang signifikan antara tingkat pendidikan pasangan usia subur (15 s/d 49 tahun) dengan keberhasilan pelaksanaan program keluarga berencana di lingkungan VI Kelurahan Sari Rejo Kecamatan Medan 
Polonia diterima dengan taraf kepercayaan $95 \%$ artinya kebenaran hipotesa dapat diyakini 95\%. Artinya ada korelasi antara tingkat pendidikan pasangan usia subur terhadap keberhasilan program keluarga berencana tersebut, pendidikan mendukung berhasilnya suatu program yang dilaksanakan oleh pemerintah

\section{DAFTAR PUSTAKA}

Handayani, L., Suharmiati, S., Hariastuti, I., \& Latifah, C. (2012). Peningkatan Informasi tentang KB: Hak Kesehatan Reproduksi yang perlu Diperhatikan oleh Program Pelayanan Keluarga Berencana. Buletin Penelitian Sistem Kesehatan, $15(3 \mathrm{Jul})$.

Mar'at. 2010. Sikap Manusia, Perubahan Serta Pengukurannya Edisi Ke-2. Bandung: Graha Indonesia.

Nora, F. I., \& Irwan, M. (2019). Empowerment On Climate Change: How Community Based Organizations Serving In Growing participation from society. Journal of Millennial Community, 1(1), 1726.

Sari, S. K., Suryani, E. S., \& Handayani, R. (2010). Hubungan konseling keluarga berencana (KB) dengan pengambilan keputusan pasangan usia subur (PUS) dalam penggunaan alat kontrasepsi. Bidan Prada: Jurnal Publikasi Kebidanan Akbid YLPP Purwokerto, 1(01).

Statistik, B. P., Kependudukan, B., \& Nasional, K. B. (2013). Survei demografi dan kesehatan Indonesia 2012. Jakarta: BPS.
Sugiyono. 2014. Metode Penelitian Pendidikan Pendekatan Kualitatif, Kuantitatif dan R\&D. Bandung: Alfabeta.

Suseno, M. R. (2011). Faktor-faktor yang

berpengaruh terhadap kebutuhan Page $\mid 56$ Keluarga Berencana yang Tidak Terpenuhi (Unmet Need for Family Planning) di Kota Kediri. Jurnal Kebidanan Pantiwilasa, 2(1).

Tim Dosen Unimed, 2004. Perkembangan Peserta Didik. Medan.

Undang-Undang Nomor 4 Pasal 22 Tahun 1992 Tentang Perumahan Dan Permukiman 